\title{
Identification of ' Candidatus Piscichlamydia salmonis' in Arctic charr Salvelinus alpinus during a survey of charr production facilities in North America
}

\author{
Andrew Draghi II ${ }^{1}$, Julie Bebak ${ }^{2,7, *}$, Stephen Daniels ${ }^{3}$, Edan R. Tulman ${ }^{1,4}$, \\ Steven J. Geary ${ }^{1,4}$, A. Brian West ${ }^{1,5}$, Vsevolod L. Popov ${ }^{6}$, Salvatore Frasca Jr. ${ }^{1,4}$ \\ ${ }^{1}$ Department of Pathobiology and Veterinary Science, ${ }^{3}$ Department of Physiology and Neurobiology, and \\ ${ }^{4}$ Center of Excellence for Vaccine Research, University of Connecticut, Storrs, Connecticut 06269, USA \\ ${ }^{2}$ The Conservation Fund's Freshwater Institute, 1098 Turner Rd., Shepherdstown, West Virginia 25443, USA \\ ${ }^{5}$ Department of Pathology, Yale University, New Haven, Connecticut 06510, USA \\ ${ }^{6}$ Electron Microscopy Laboratory, Department of Pathology, The University of Texas Medical Branch, Galveston, \\ Texas 77555-0609, USA \\ ${ }^{7}$ Present address: Aquatic Animal Health Research Laboratory, Agricultural Research Service, \\ US Department of Agriculture, 990 Wire Road, Auburn, Alabama 36832, USA
}

\begin{abstract}
Arctic charr Salvelinus alpinus production facilities, nonproduction water sources and effluents in the United States and Canada were sampled to determine if chlamydiae associated with epitheliocystis were present in water and were associated with inclusions of epitheliocystis in gill tissue. Gills from 607 fish from 13 sites were processed for histopathologic examination and DNA extraction. Water was collected from 21 locations for DNA testing. Eighteen fish from one location had inclusions of epitheliocystis with proliferative and inflammatory gill lesions. Inclusions were stained using the Gimenez technique and, at the ultrastructural level, consisted of intracytoplasmic membrane-bound vacuoles containing reticulate and intermediate bodies in a fibrillar matrix. PCR using Order Chlamydiales-specific primers performed on DNA extracts from 12 of 13 infected fish yielded amplicons that were identical to (GQ302988) or differed at one base from (GQ302987) the 16S ribosomal RNA gene signature sequence of 'Candidatus Piscichlamydia salmonis', which is the chlamydia that was previously identified in epitheliocystis inclusions of farmed Atlantic salmon. In situ hybridization using a $\sim 1.5 \mathrm{~kb}$ riboprobe corresponding to the 'Candidatus Piscichlamydia salmonis' 16S rRNA genetic sequence (AY462244) confirmed its presence within Arctic charr gill inclusions. DNA isolated from water samples was tested by Chlamydiales-specific PCR and yielded 54 partial 16S rRNA genetic sequences spanning the signature region; however, no 16S rRNA genetic sequences associated with epitheliocystis were identified. This is the first report of 'Candidatus Piscichlamydia salmonis' associated with epitheliocystis in Arctic charr, the first identification of 'Candidatus Piscichlamydia salmonis' from a freshwater production location, and the first reported occurrence in North America.
\end{abstract}

KEY WORDS: Arctic charr · Epitheliocystis - 'Candidatus Piscichlamydia salmonis' • Chlamydia · Water supply $\cdot$ Survey $\cdot$ Environment

\section{INTRODUCTION}

Epitheliocystis is an infectious disease that causes morbidity and mortality in cultured freshwater and marine finfish. It was first identified by Hoffman et al.
(1969) in bluegill Lepomis macrochirus, and has since been described worldwide in $>50$ freshwater and marine fish species, including many ornamental and commercially relevant species (Wolke et al. 1970, Paperna 1977, Zachary \& Paperna 1977, Rourke et al. 
1984, Bradley et al. 1988, Lewis et al. 1992, Groff et al. 1996, Nylund et al. 1998, Crespo et al. 1999, Draghi et al. 2004, 2007, Kim et al. 2005, Nowak \& LaPatra 2006). Under aquaculture conditions, disease associated with epitheliocysts has been reported in a number of species (Paperna 1977, Crespo et al. 1990, Groff et al. 1996, Nylund et al. 1998, Goodwin et al. 2005, Kim et al. 2005, Draghi et al. 2007). Typically, branchial epithelial cells are affected, but infections of the epidermis and other tissues have been reported (Hoffman et al. 1969). Epitheliocystis is morphologically characterized by hypertrophy of gill and skin epithelial cells that contain large, membrane-bound, basophilic, granular, cytoplasmic inclusions. The response of the host gill tissue can range from no reaction by the surrounding branchial epithelium, i.e. nonproliferative response (Paperna \& Alves de Matos 1984, Zimmer et al. 1984, Langdon et al. 1991, Groff et al. 1996, Crespo et al. 1999, Draghi et al. 2004) to a hyperplastic reaction characterized by epithelial cell proliferation and fusion of lamellae, i.e. proliferative response (Paperna 1977, Paperna \& Alves de Matos 1984, Crespo et al. 1990, Frances et al. 1997, Nylund et al. 1998, Nowak \& Clark 1999, Szakolczai et al. 1999, Draghi et al. 2004, 2007). This severe form of the disease is similar to what has been termed as proliferative gill inflammation (PGI) in Atlantic salmon (Kvellestad et al. 2005). PGI appears to be a multifactorial condition. The presence of epitheliocystis inclusions in Atlantic salmon concurrent with infections by Trichodina sp. and virus-like particles (Nylund et al. 1998), paramyxovirus (Kvellestad et al. 2005), or poxvirus (Nylund et al. 2008), as well as the presence of epitheliocystis inclusions in cultured pacu Piaractus mesopotamicus co-infected with Trichodina sp. and Gyrodactylus sp. (Szakolczai et al. 1999), have only further obfuscated the causal relationship between epitheliocystis and proliferative and inflammatory host tissue reactions.

Since its initial identification, the etiology of epitheliocystis was thought to be a chlamydia- or rickettsialike bacterium (Hoffman et al. 1969, Paperna 1977, Zachary \& Paperna 1977, Rourke et al. 1984, Crespo et al. 1999). Histological, ultrastructural and antigenic studies have described chlamydia-like staining characteristics and biphasic life stages that indicate infection by chlamydiae (Wolke et al. 1970, Rourke et al. 1984, Groff et al. 1996, Nylund et al. 1998, Crespo et al. 1999, Nowak \& Clark 1999, Draghi et al. 2004, 2007). There are reports of positive labeling with antichlamydial lipopolysaccharide (LPS) antibodies (Groff et al. 1996, Draghi et al. 2004, 2007, Meijer et al. 2006), although in some instances, these group-specific chlamydial antibodies failed to label life forms (elementary and reticulate bodies) that are typical of the Chlamydiae (Langdon et al. 1991, Crespo et al. 1999,
Nowak \& Clark 1999, Meijer et al. 2006, Nowak \& LaPatra 2006). Recently, Draghi et al. (2004) identified a novel chlamydia associated with epitheliocystis in marine farmed Atlantic salmon Salmo salar and proposed the name 'Candidatus Piscichlamydia salmonis'. Various investigators have identified and characterized still other chlamydiae associated with epitheliocystis. Meijer et al. (2006), using archived formalinfixed paraffin-embedded (FFPE) tissue, identified Order Chlamydiales sequences in the leafy seadragon Phycodurus eques, silver perch Bidyanus bidyanus and barramundi Lates calcarifer, and used 16S sequence end-labeled DNA probes and immunocytochemistry to localize chlamydial genetic sequences and antigenic features to epitheliocystis inclusions. More recently, Draghi et al. (2007) identified a Neochlamydia sp. associated with epitheliocystis in the Arctic charr Salvelinus alpinus, and Karlsen et al. (2008) identified another novel chlamydia associated with epitheliocystis in salmonid fish from fresh water. This agent, 'Candidatus Clavochlamydia salmonicola', is proposed to be a novel member of a novel genus within the Family Chlamydiaceae by $16 \mathrm{~S}$ rRNA genebased phylogenetic analysis and has head-and-tail forms that were described previously in other salmonids infected with chlamydiae associated with epitheliocystis (Bradley et al. 1988, Draghi et al. 2004). These results suggest that epitheliocystis is associated with a diverse number of chlamydiae that may or may not be host-specific. Environmental chlamydiae, e.g. Parachlamydia and Neochlamydia spp., can infect and replicate within protistan hosts, such as Acanthamoeba spp. and Hartmannella spp. (Amann et al. 1997, Everett et al. 1999, Horn et al. 2000, Corsaro et al. 2002, Collingro et al. 2005); this suggests that the water column and its associated protistan fauna may serve as a reservoir of chlamydial agents of epitheliocystis. Order Chlamydiales 16S rRNA genetic sequences have been amplified from many aquatic environments, including activated sludge and marine lake sediments in Antarctica (Corsaro et al. 2002), and several genetic sequences of chlamydiae have been amplified from freshwater ponds (Fritsche et al. 2000, Horn et al. 2000, Corsaro \& Venditti 2004, Collingro et al. 2005, Corsaro \& Greub 2006). Given the association of several members of the Order Chlamydiales with epitheliocystis and the implication of amoebae as a possible reservoir of infection, a next logical step would be to identify these chlamydiae from the water column and determine whether resident fish are infected with these same chlamydiae.

The use of $16 \mathrm{~S}$ and 23S rRNA sequence data has allowed the reorganization of the Order Chlamydiales and has been exploited in amplification-based assays for identification of microbial pathogens (Engel \& 
Ganem 1987, Everett \& Andersen 1997, Palys et al. 1997, Pettersson et al. 1997, Everett et al. 1999, Fritsche et al. 2000, Horn et al. 2000, Horn \& Wagner 2001, Draghi et al. 2004, 2007, Corsaro \& Greub 2006, Meijer et al. 2006). The objective of this study was to identify, then compare 16S rRNA genetic sequences amplified from Arctic charr with inclusions of epitheliocystis and those amplified from farm water supplies, farm effluents and non-aquaculture sources in order to determine an association between chlamydiae of epitheliocystis and environmental locations of chlamydiae.

\section{MATERIALS AND METHODS}

Gill and water samples. Gill and water samples were collected from 13 Arctic charr farms in the USA (5 farms) and Canada (8 farms) between 1 May 2005 and 30 September 2005. Farms were chosen to represent a wide geographic area and were located in the northeast and northwest USA, and eastern and central Canada. The total number of farms and fish sampled was determined by the availability of time for farm visits, and financial resources for histology, electron microscopy, molecular assays, and travel.

During each farm visit, information about water supply characteristics and previous history of gill disease of bacterial etiology was recorded. Unless the owner or manager requested that a smaller number be sampled, gill tissues from 50 fish were collected. To increase the probability that chlamydiae would be detected, if present, Arctic charr $>6$ mo old and/or with clinical signs of gill disease or a previous history of fish health problems were preferentially sampled. Charr were euthanized by immersion in $250 \mathrm{mg} \mathrm{l}^{-1} \mathrm{MS}-222$ (tricaine methanesulfonate, FINQUEL, Argent Chemical Laboratories). A $15 \mathrm{~mm}$ piece of the left first gill arch was fixed in neutral buffered $10 \%$ formalin and a $3 \mathrm{~mm}$ piece was placed in Qiagen ATL tissue lysis buffer (Qiagen), for use if formalin-fixed tissues did not yield amplifiable DNA in subsequent PCR experiments. At each farm, 11 of water was collected from the water supply as it entered the culture units. Effluent was also collected if accessible; otherwise, a sample was collected directly from a culture unit. Water was also collected from 8 locations for which no matching fish tissues were collected. Four of these sites were not fish farms. All samples (on wet ice) were sent by overnight courier to the Connecticut Veterinary Medical Diagnostic Laboratory (Storrs, CT) and processed for DNA extraction upon arrival.

Histopathology. Formalin-fixed gill samples were trimmed, processed routinely for embedding in paraffin, and sectioned at $4 \mu \mathrm{m}$. All gill sections were stained with hematoxylin and eosin (H\&E) (Sheehan \&
Hrapchak 1980). Gill sections were examined by light microscopy, and additional sections were cut from blocks with evidence of epitheliocystis inclusions. Gill sections were then stained using the Gimenez (PVK modification) technique (Gimenez 1964, Culling 1974), which was previously shown to highlight epitheliocysts in Arctic charr (Draghi et al. 2007).

Transmission electron microscopy. Tissues with histologic evidence of epitheliocystis inclusions that amplified chlamydial 16S rRNA genetic sequences were selected for examination by transmission electron microscopy (TEM). All tissues for TEM were processed via a rapid microwave technique (Giberson et al. 1997, 2003) using a microwave processor (Pelco Model 3441), 3430 microwave power controller, 3420 microwave load cooler, a vacuum chamber and a cold spot water recirculation system (Ted Pella). Paraffin blocks that were originally used for histochemical and molecular studies were deparaffinized using xylene, then rehydrated through a descending gradient of ethanol. Tissues were trimmed to fit flat-bottom BEEM capsules (Electron Microscopy Sciences). The series of processing steps included aldehyde fixation in McDowell Trump's fixative, i.e. $4 \%$ formaldehyde and $1 \%$ glutaraldehyde in a buffer of $176 \mathrm{mOsm}^{-1}$ (McDowell \& Trump 1976), under $25 \mathrm{~mm} \mathrm{Hg}$ at $37^{\circ} \mathrm{C}$, using $450 \mathrm{~W}$ of power for $40 \mathrm{~s}$. Tissues were rinsed in 0.1 M HEPES buffer, then post-fixed in cold $1 \% \mathrm{OsO}_{4}$ in $0.1 \mathrm{M}$ HEPES buffer under $25 \mathrm{~mm} \mathrm{Hg}$ vacuum at $37^{\circ} \mathrm{C}$; this step was conducted at $100 \mathrm{~W}$ for 2 min each of successive power on, off, and on. Tissues were rinsed in 0.1 maleate buffer ( $\mathrm{pH}$ 5.2) at $37^{\circ} \mathrm{C}$ under no vacuum, using $250 \mathrm{~W}$ for a $1 \mathrm{~min}$ hold, $40 \mathrm{~s}$ pause, and $3 \mathrm{~min}$ hold; this step was repeated twice. En bloc uranyl acetate staining was conducted twice with cold $1 \%$ uranyl acetate in $0.1 \mathrm{M}$ maleate buffer under $25 \mathrm{~mm}$ $\mathrm{Hg}$ pressure at $37^{\circ} \mathrm{C}$, using $100 \mathrm{~W}$ for $2 \mathrm{~min}$ each of successive power on, off, and on. Dehydration was conducted through an ascending gradient of alcohol $(50,70,95$ and $100 \%)$ under no vacuum at $37^{\circ} \mathrm{C}$ and $300 \mathrm{~W}$ for $40 \mathrm{~s}$. LR White resin (medium grade, London Resin) infiltration was conducted twice with $3: 1$ ethanol:LR White resin at $25 \mathrm{~mm} \mathrm{Hg}$ pressure, $45^{\circ} \mathrm{C}$, and $450 \mathrm{~W}$ for $5 \mathrm{~min}$, then 3 times with 1:1 ethanol:LR White resin, and 3 times with $100 \%$ LR White resin. Resin polymerization was conducted with the BEEM capsules submerged in water at $800 \mathrm{~W}$ for $10 \mathrm{~min}$ at $60^{\circ} \mathrm{C}, 10 \mathrm{~min}$ at $70^{\circ} \mathrm{C}$ and $20 \mathrm{~min}$ at $80^{\circ} \mathrm{C}$. Total time of tissue processing was $\sim 4 \mathrm{~h}$. Ultrathin sections were stained with $1 \%$ lead citrate and viewed using an electron microscope (Philips) at $80 \mathrm{kV}$.

DNA extraction. Water: Water was filtered through a nylon filter (0.2 $\mu \mathrm{m}$, Nalgene Nunc International) under vacuum. The membrane was cut aseptically from the filter apparatus with sterile disposable scalpel 
blades, placed in a $15 \mathrm{ml}$ conical tube with $10 \mathrm{ml}$ sterile $1 \times$ phosphate buffered saline (PBS) and vortexed for $3 \mathrm{~min}$. The membrane was removed, the conical tube was centrifuged at $9200 \times g$ (Eppendorf $5810 \mathrm{R}$ centrifuge, Eppendorf $\mathrm{AG}$ ) at $4^{\circ} \mathrm{C}$ for $30 \mathrm{~min}$, and the supernatant was removed. DNA was then extracted from the resulting pellet using the DNeasy tissue kit (Qiagen). The pellet was lysed with $180 \mu \mathrm{l}$ Qiagen ATL tissue lysis buffer and $50 \mu \mathrm{l}$ Proteinase $\mathrm{K}$, vortexed, and incubated at $55^{\circ} \mathrm{C}$ overnight. The following day, samples were centrifuged at $1200 \times g$ for 5 min to allow the lysate to settle. The lysate was then transferred to a $1.5 \mathrm{ml}$ microfuge tube. Microfuge tubes were heated to $100^{\circ} \mathrm{C}$ for $20 \mathrm{~min}$. To prevent co-purification of RNA with genomic DNA, $20 \mu \mathrm{l}$ RNase A (100 $\mathrm{mg} \mathrm{ml}^{-1}$, Qiagen) was added to each lysate and the mixture briefly vortexed. Lysates were then incubated at room temperature for $5 \mathrm{~min}$. Extraction was conducted as per manufacturer's directions. DNA was stored in $1.5 \mathrm{ml}$ microfuge tubes at $4^{\circ} \mathrm{C}$ or frozen at -35 or $-80^{\circ} \mathrm{C}$ for later use.

Gills: Genomic DNA was extracted from all Arctic charr gill samples with histopathologic evidence of epitheliocystis inclusions. Fixed tissue was used for DNA extraction to provide continuity of histologic, ultrastructural and in situ hybridization data with amplified 16S rRNA genetic sequences. A $50 \mu \mathrm{m}$ section was cut from each paraffin block of interest, and the tissue was deparaffinized with xylene, then washed with $100 \%$ ethanol. DNA was extracted using the Qiagen DNeasy tissue kit (Qiagen) according to the manufacturer's mouse-tail protocol, with several modifications. Tissues were lysed in $180 \mu \mathrm{l}$ of tissue lysis buffer (ATL buffer, Qiagen) to which $50 \mu \mathrm{l}$ of proteinase $\mathrm{K}$ was added, and then incubated at $55^{\circ} \mathrm{C}$ overnight. The next day, lysates were heated to $100^{\circ} \mathrm{C}$ for $20 \mathrm{~min}$ to facilitate the release of prokaryotic DNA. RNase A was added to each sample to prevent copurification of RNA. Column binding, washing, and elution of DNA were performed according to the manufacturer's instructions. DNA extractions were aliquoted, then stored at $4^{\circ} \mathrm{C}$ for immediate use or frozen at $-35^{\circ}$ or $-80^{\circ} \mathrm{C}$.

PCR and cloning. All DNA extractions from gill and water samples were tested for their ability to support amplification-based experiments by PCR using universal 18S rDNA primers (18e and 18i) (Hillis \& Dixon 1991) to yield a 440 bp product, as described previously (Draghi et al. 2004). Samples that amplified 18S rDNA were considered useable for 16S rRNA genebased PCR experiments.

Oligonucleotide primers to conserved sites flanking the signature region of the 16S rRNA gene of members of the Order Chlamydiales were used to amplify a $\sim 300 \mathrm{bp}$ fragment from the $5^{\prime}$ end of the gene (16SIGF,
5'-CGG CGT GGA TGA GGC AT-3', and 16SIGR, 5'TCA GTC CCA GTG TTG GC-3') (Everett et al. 1999). Primers for all PCR experiments were synthesized by Invitrogen and rehydrated to a stock concentration of 100 pmol. All 16S rDNA PCR products were amplified in individual $50 \mu \mathrm{l}$ reaction mixtures containing 100-150 ng of sample DNA, $5 \mu \mathrm{l}$ of $10 \times$ Qiagen buffer $\left(100 \mu \mathrm{M}\right.$ Tris- $\mathrm{HCl}, \mathrm{pH} 8.3,500 \mathrm{mM} \mathrm{KCl}, 15 \mathrm{mM} \mathrm{MgCl}_{2}$,

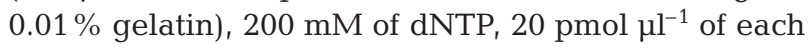
primer, and $1 \mathrm{U}$ of Qiagen HotStar Taq polymerase (Qiagen) using thermal cyclers (Perkin-Elmer Model 2400, Applied Biosystems). PCR conditions were as follows: 15 min incubation at $95^{\circ} \mathrm{C}$, followed by 40 cycles of $30 \mathrm{~s}$ at $94^{\circ} \mathrm{C}, 40 \mathrm{~s}$ at $60^{\circ} \mathrm{C}$, and $30 \mathrm{~s}$ at $72^{\circ} \mathrm{C}$. A $7 \mathrm{~min}$ final extension step at $72^{\circ} \mathrm{C}$ was performed to extend any incomplete amplicons. Products were separated by electrophoresis in 1.5 to $2 \%$ agarose gels and visualized by ethidium bromide staining and UV transillumination. Images were recorded digitally using a Stratagene Eagle Eye II still video image capture system (Stratagene). All 16S rDNA PCR products were excised and purified from agarose gels (Zymoclean Gel DNA recovery kit, Zymo Research), and then submitted for direct sequencing (MWG Biotech).

PCR products from water samples with evidence of multiple templates, i.e. multiple chlamydiae or related 16S rDNA templates, were re-amplified using primers and protocols that were previously described for near full-length 16S rRNA gene amplification (Draghi et al. 2004). Primers for this assay consisted of 16 SIGF and 16SB1 5'-TCA GGY TAC CTT GTT ACG ACT T-3' (Fukatsu \& Nikoh 1998). PCR products were purified and ligated into a plasmid vector (pCRII TOPO TA vector, Invitrogen) and cloned. At least 5 white colonies were selected, grown, and screened by $\mathrm{PCR}$, and plasmid DNA was purified using the FastPlasmid mini kit (Eppendorf AG).

DNA sequencing and analysis. Nucleotide sequences of amplicons and cloned PCR products were generated by dideoxynucleotide chain termination DNA sequencing reactions using the signature sequence primers 16SIGF and 16SIGR (Everett et al. 1999). Signature sequence composition was determined by assembling $\mathrm{ABI}$ sequence files of sense and anti-sense strands using Sequencher for Macintosh version 4.5 (Gene Codes). In the case of amplification products from gill samples with epitheliocystis, ABI trace files were base-called using phred (Ewing et al. 1998), sequences assembled using phrap (www.phrap.org/), and assemblies evaluated using consed (Gordon et al. 1998). Standard nucleotide-nucleotide sequence comparisons were made by conducting BLAST-n searches (Altschul et al. 1990, 1997) of GenBank submissions to the National Center for Biotechnology Information database (www.ncbi.nlm.nih.gov) to determine se- 
quences with the highest identity to those amplified during the survey.

Accession of nucleotide sequences. Two $16 \mathrm{~S}$ ribosomal RNA gene signature sequences with 99 and $100 \%$ nucleotide sequence identity to those of known sequences of 'Candidatus Piscichlamydia salmonis' were submitted to GenBank and were assigned the GenBank accession numbers GQ302987 and GQ302988, respectively. The third sequence was unique, demonstrating $91 \%$ nucleotide sequence identity with an uncultured bacterium clone FW 1023-035 (EF693276), and was submitted to GenBank and assigned the accession number FJ168566.

In situ hybridization using riboprobes. In situ hybridization (ISH) was accomplished using riboprobes that were generated by in vitro transcription of the cloned $\sim 1.5 \mathrm{~kb}$ 16S rRNA gene sequence amplified from Atlantic salmon gills infected with 'Candidatus Piscichlamydia salmonis' (AY462244) (Draghi et al. 2004). The transcription protocol was based on protocols that were previously described by Brown (1998) and Draghi et al. $(2004,2007)$, using a dual promoter transcription vector (pCRII TOPO Vector, Invitrogen) and a high-yield transcription kit (Ampliscribe Sp6/T7, Epicentre Biotechnologies) in combination with $10 \times$ digoxigenin-labeled nucleotide mix (Roche Applied Science). To serve as a nonhomologous sequence control riboprobe, the T7 control template (Epicentre Biotechnologies), which is a $\sim 1.4 \mathrm{~kb}$ lambda DNA template, was transcribed in identical fashion. Concentrations of transcribed riboprobe were estimated by dot blot analysis.

Riboprobes were used in non-isotopic in situ hybridization experiments based on procedures described by Gan et al. (1994), Brown (1998) and Draghi et al. (2004, 2007). Gill sections stained with H\&E were examined by light microscopy for number and distribution of inclusions, and successive serial tissue sections (4 $\mu \mathrm{m})$ were mounted unstained on charged glass slides. Sections were heated to $70^{\circ} \mathrm{C}$ for $20 \mathrm{~min}$, deparaffinized in three $3 \mathrm{~min}$ washes of xylene, and rehydrated for $15 \mathrm{~min}$ at room temperature (RT); sections were then digested with $10 \mathrm{ng} \mathrm{\mu l}^{-1}$ of proteinase $\mathrm{K}$ at $37^{\circ} \mathrm{C}$ for $10 \mathrm{~min}$, and covered with pre-hybridization solution (Ambion) for $1.5 \mathrm{~h}$ at $42^{\circ} \mathrm{C}$. Slides were then heated to $95^{\circ} \mathrm{C}$ for 5 min to denature target DNA and RNA, covered with $\sim 100 \mu \mathrm{l}$ of hybridization solution (50 ng digoxigenin-labeled riboprobe $(100 \mu \mathrm{l})^{-1}$ pre-hybridization solution, Applied Biosystems/Ambion) per slide, coverslipped, overlaid with parafilm, and allowed to hybridize overnight at $42^{\circ} \mathrm{C}$ in a humidified slide moat (Fisher Scientific). After hybridization, slides were washed in $4 \times$ saline sodium citrate (SSC), then in $2 \times \mathrm{SSC}$ with $1 \%$ sodium dodecyl sulphate (SDS) at $55^{\circ} \mathrm{C}$ for $20 \mathrm{~min}$, followed by $1 \times \mathrm{SSC}$ with
$0.1 \% \mathrm{SDS}$ at $50^{\circ} \mathrm{C}$ for $20 \mathrm{~min}, 1 \times \mathrm{SSC}$ for $10 \mathrm{~min}$ at $\mathrm{RT}$ and $0.1 \times \mathrm{SSC}$ for $15 \mathrm{~min}$ at RT. Hybridization signals were developed by washing sections in buffer I (0.1 M Tris, $0.15 \mathrm{M} \mathrm{NaCl}, \mathrm{pH} 7.5$ ) for $5 \mathrm{~min}$, then incubating sections for $2 \mathrm{~h}$ at $37^{\circ} \mathrm{C}$ in a humidified chamber with 100-200 $\mu \mathrm{l}$ of buffer I containing $2 \%$ sheep serum and anti-digoxigenin Fab fragments conjugated to alkaline phosphatase at 1:250 dilution (Roche Applied Science). Slides received one 15 min wash in buffer I, and were then washed twice in Tris buffered saline Tween (TBST) (0.15 M NaCl, $2.7 \mathrm{mM} \mathrm{KCl}, 25 \mathrm{mM}$ Tris, $0.05 \%$ Tween 20, pH 7.6) for $5 \mathrm{~min}$. Chromogenic signals were developed using the Dako Cytomation liquid permanent red substrate system (Dako Cytomation) with tetramasole (Sigma) to quench endogenous alkaline phosphatase activity. Slides were counterstained and coverslipped according to manufacturer instructions (Dako Cytomation).

\section{RESULTS}

\section{Farms, fish and water}

A total of 607 fish from 13 farms (5 USA, 8 Canada) and 45 water samples from fish farms and nonfarm sources were collected. A total of 22 water samples were from surface water (e.g. stream, river, or culture system), 22 from a ground water source (well or spring), and 1 was municipal. One farm in Canada, which was supplied by well water, reported a history of gill disease consistent with epitheliocystis. Five farms reported a prior history of gill disease that was associated with poor water quality or parasite infestation, but not of a bacterial etiology.

\section{Epitheliocystis}

Histopathology

Histologic sections of gill samples from 607 Arctic charr were reviewed by light microscopy. Sections from 18 charr had bacterial inclusions that were consistent with those of epitheliocystis (Wolke et al. 1970, Rourke et al. 1984, Nylund et al. 1998, Draghi et al. 2004, 2007, Nowak \& LaPatra 2006), accompanied by proliferative and inflammatory lesions. The 18 fish with bacterial inclusions were from the farm in Canada with a history of epitheliocystis. A total of 25 fish were sampled from this farm. Five fish were sampled from each of 5 tanks and had none to severe clinical signs of respiratory distress. Gross pathology consisted of swollen, mucous-covered gills and varied from minimal to severe. Histopathologic gill changes included 
multifocal to diffuse, basal to complete, interlamellar filling by hyperplastic epithelium, foci of lamellar fusion and epithelial bridging. An inflammatory infiltrate of neutrophils with increased numbers of intraepithelial eosinophilic granular cells was present (Fig. 1). Inclusions were differentially stained by the Gimenez staining technique (Fig. 2).

\section{Transmission electron microscopy}

Epitheliocystis inclusions were membrane-bound vacuoles within the cytoplasm of epithelial cells lining lamellae (Fig. 3A). Vacuoles contained reticulate and intermediate bodies, which were spherical to elongate. Sizes ranged from 0.7 to $1.5 \mu \mathrm{m}$ in length for elongate forms and 0.3 to $0.7 \mu \mathrm{m}$ in diameter for spherical forms. An amorphous, osmiophilic, fibrillar, extracellular matrix surrounded reticulate and intermediate bodies (Fig. 3B). No inclusions were identified in cells other than epithelial cells. No other infectious agents, such as virus particles, were identified in the examined lamellar epithelial cells.

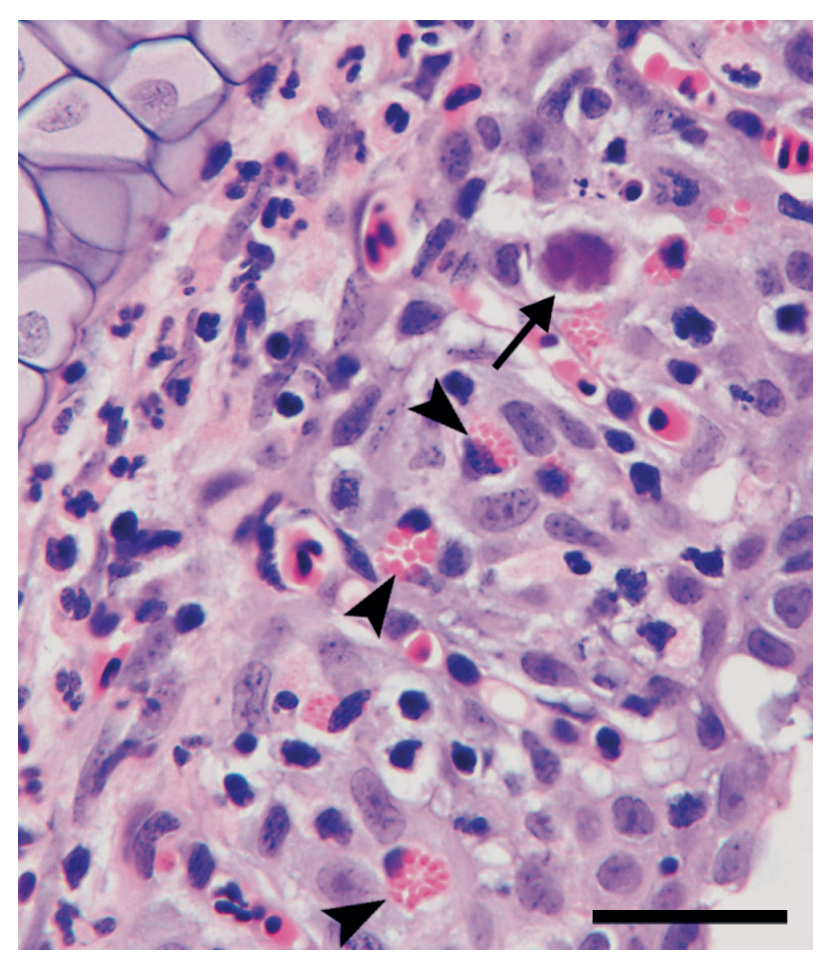

Fig. 1. Salvelinus alpinus. Proliferative gill lesion associated with 'Candidatus Piscichlamydia salmonis'. There is interlamellar filling by hyperplastic epithelium together with intra-epithelial infiltrates of eosinophilic granular cells (arrowheads) and infiltrates of neutrophils in the interstitium of the filament. A basophilic intracytoplasmic inclusion (arrow) is present in an epithelial cell. Staining technique: hematoxylin and eosin (H\&E). Scale bar $=20 \mu \mathrm{m}$

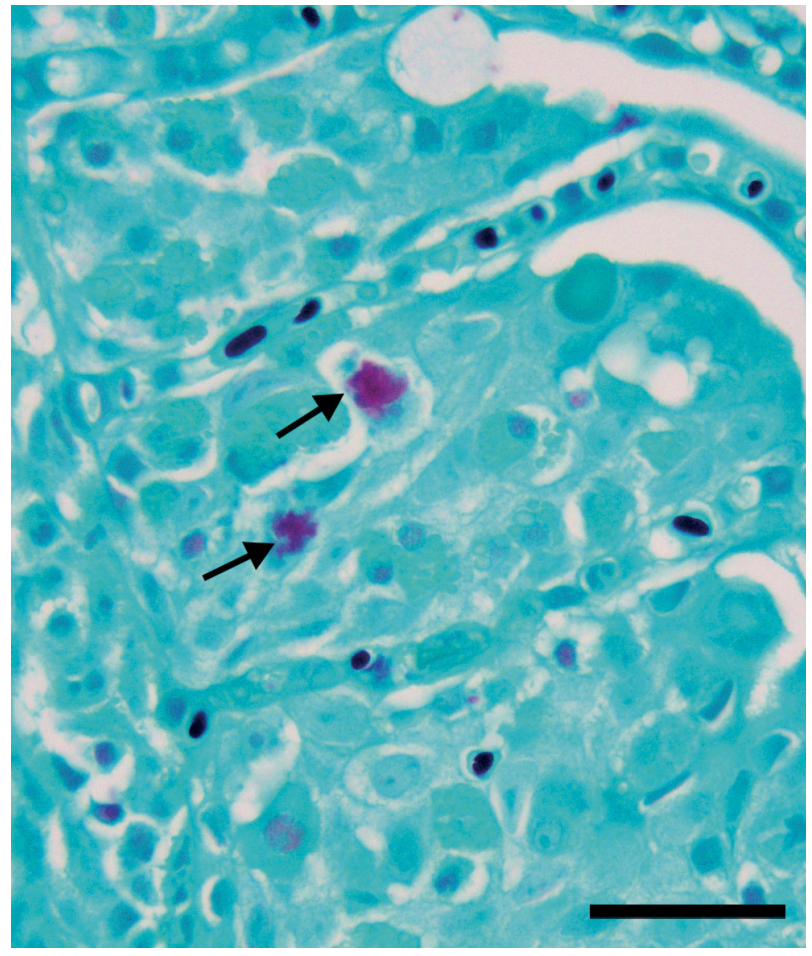

Fig. 2. Salvelinus alpinus. Chlamydial inclusions of 'Candidatus Piscichlamydia salmonis' highlighted by the Gimenez staining technique in a proliferative gill lesion. Intracytoplasmic inclusions located in 2 epithelial cells stain red-purple (arrows), whereas the cytoplasm of other epithelial cells filling

the interlamellar space stains green. Scale bar $=20 \mu \mathrm{m}$

DNA sequencing and analysis

All 18 gills that were tested using PCR protocols targeting $18 \mathrm{~S}$ rDNA and the signature sequence region of the 16S rRNA gene of the Chlamydiales (Everett et al. 1999) amplified host $18 \mathrm{~S}$ rDNA; 13 of these 18 samples yielded 16S rRNA genetic sequence data. All 13 16S rDNA amplicons were obtained from Arctic charr gill samples with histological and ultrastructural evidence of epitheliocystis inclusions. Twelve of the $1316 \mathrm{~S}$ rDNA amplicons were represented by 1 of 2 sequences (GenBank accession numbers GQ302987 and GQ302988) that were nearly identical (GQ302987) or identical (GQ302988) to signature regions of known sequences classified as 'Candidatus Piscichlamydia salmonis' in GenBank (as exemplified in accession number AY462244). Ten of these 12 amplicon sequences differed from the 16S rDNA signature region sequence of 'Candidatus Piscichlamydia salmonis' by a single base (G) at position 143 of the amplicon (position 126 of GenBank accession number GQ302987). The other 2 of the 12 amplicon sequences (GQ302988) were identical to the 16S rDNA signature region sequence of 'Candidatus Piscichlamydia salmonis'. The thirteenth amplicon 

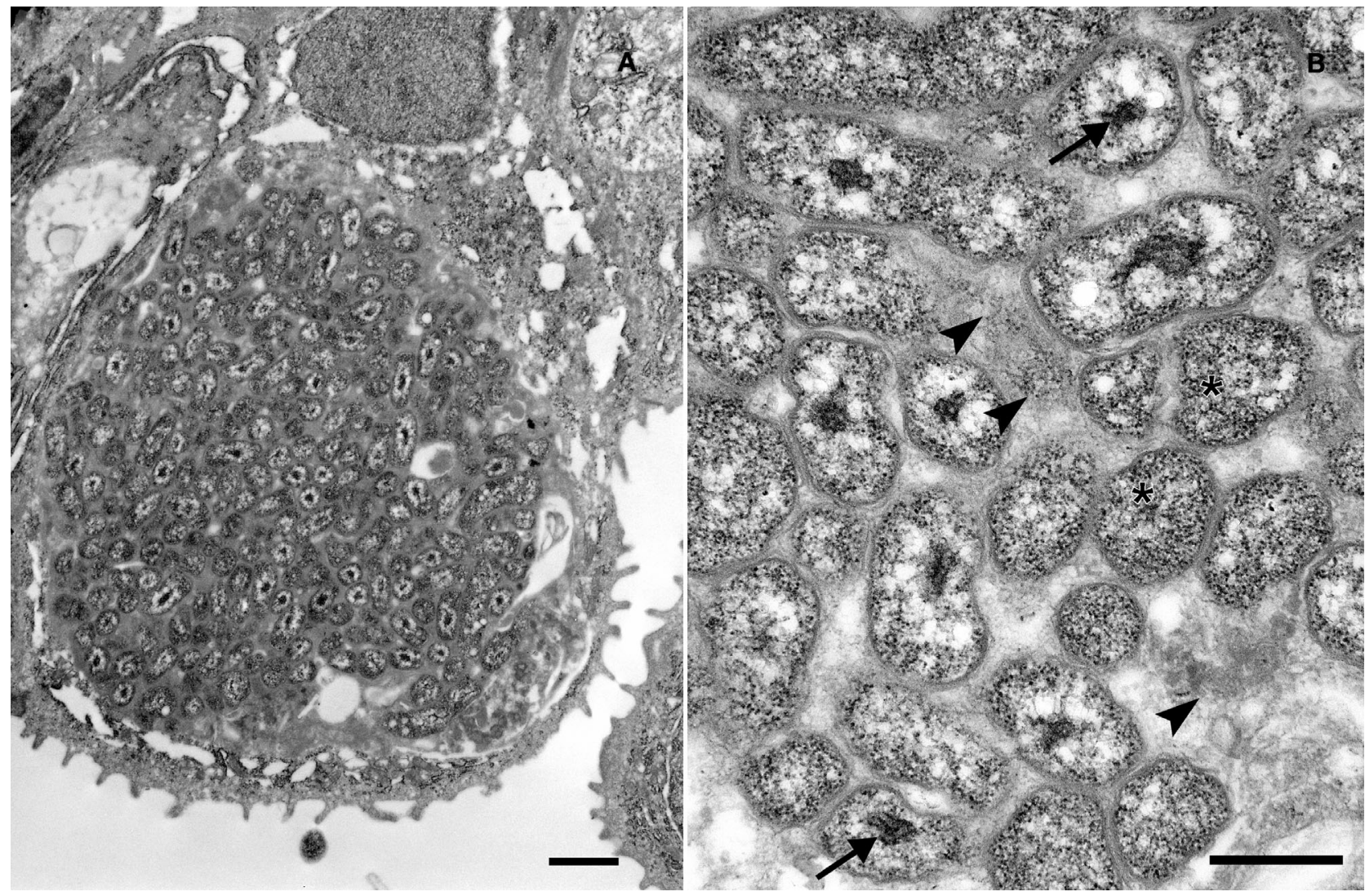

Fig. 3. Salvelinus alpinus. Transmission electron photomicrographs of an epitheliocystis inclusion of 'Candidatus Piscichlamydia salmonis' in a gill that was reprocessed after formalin fixation and paraffin embedment. (A) The cytoplasm of an epithelial cell is expanded by a membrane-bound vacuole containing spherical to elongate reticulate and intermediate bodies in a fibrillar matrix. Scale bar $=1.0 \mu \mathrm{m}$. (B) Higher magnification reveals reticulate bodies $(*)$ and intermediate bodies with condensed central or paracentral nucleoid (arrows) located within a moderately osmiophilic, fibrillar matrix (arrowheads) of varying density. Scale bar $=0.5 \mu \mathrm{m}$

represented a third, and unique,16S rDNA signature region sequence (GenBank accession number FJ168566) that had $>80 \%$ nucleotide identity to members of the Chlamydiales and was most similar to an uncultured bacterium clone FW 1023-035 (GenBank accession no. EF693276, 91 \% nucleotide identity).

\section{In situ hybridization}

Epitheliocystis inclusions in branchial epithelium of gills that amplified the 'Candidatus Piscichlamydia salmonis' 16S rRNA gene signature region sequence and provided ultrastructural evidence of the presence of a chlamydia were specifically labeled with the $\sim 1.5 \mathrm{~kb}$ riboprobe that was transcribed from the 'Candidatus Piscichlamydia salmonis' 16S rRNA genetic sequence (AY462244). Inclusions in histologic sections of the same gill samples that were incubated with the nonhomologous probe or with no probe were free of labeling (Fig. 4).

\section{Water samples}

DNA sequencing and analysis

Nine water samples from 8 locations yielded 10 sequences with no evidence of multiple templates. Seventeen water samples from 9 farms and 3 nonproduction sites had evidence of multiple templates (5 source, 7 effluent and 5 culture water); thus, the PCR products of these samples were cloned. The presence of inserts was confirmed by PCR prior to sequencing in all instances. A total of 18 water samples failed to amplify any $16 \mathrm{~S}$ rRNA gene signature region sequences (13 source, 4 effluent and 1 culture water sample) and, hence, were not studied further. Two water samples that were taken from the well water source and from a clinically affected tank were from the aquaculture facility that submitted fish with gross gill pathology, histopathological evidence of epitheliocystis, and molecular evidence that epitheliocystis inclusions were associated with 'Candidatus Piscichlamydia salmonis'. 

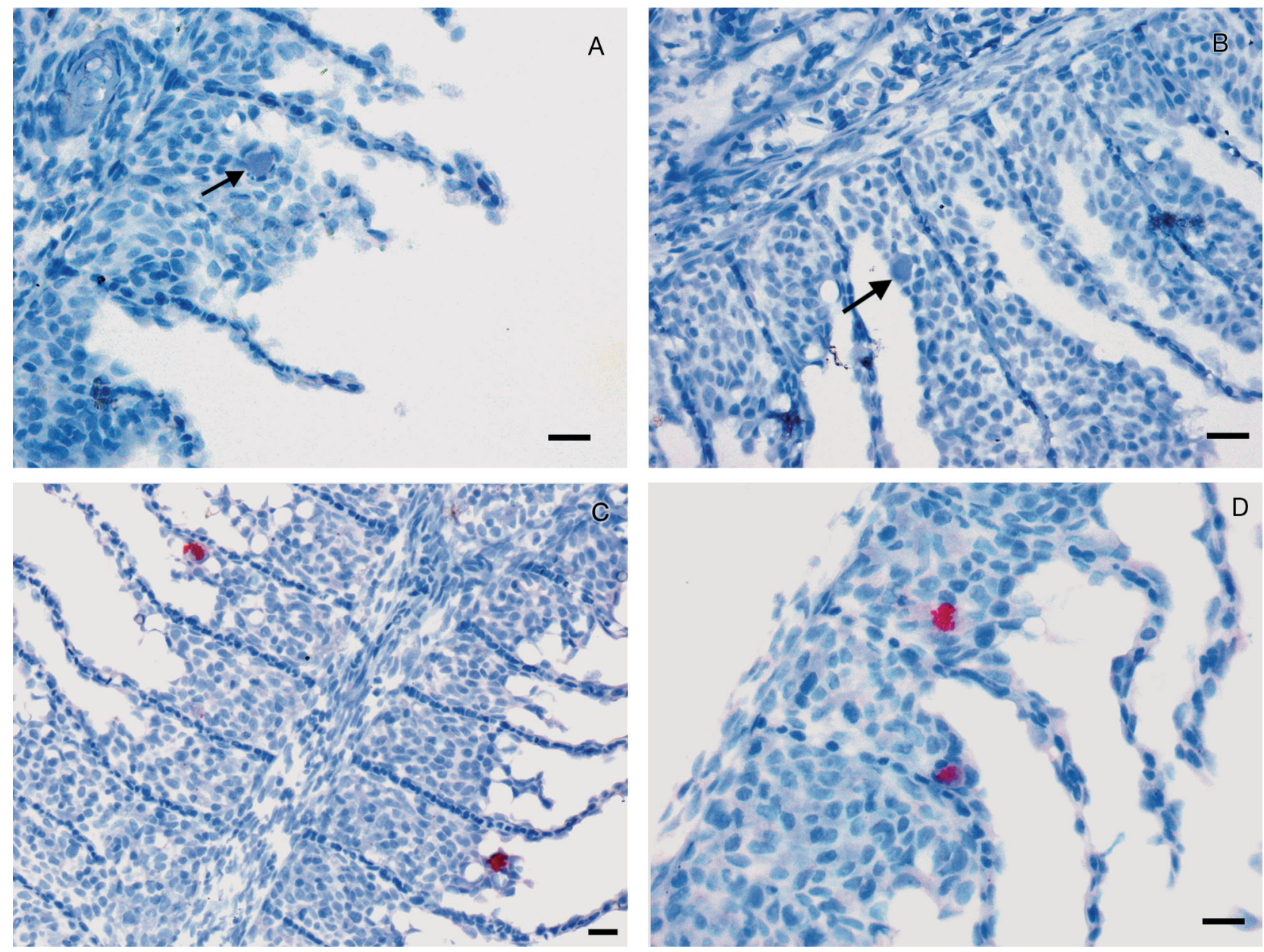

Fig. 4. Salvelinus alpinus. In situ hybridization performed on gill sections with epitheliocystis inclusions using a 1487 bp digoxigenin-labeled riboprobe transcribed from 'Candidatus Piscichlamydia salmonis' 16S rDNA. No labeling of inclusions (arrows) was detected in sections that received (A) no riboprobe, or (B) T7 control digoxigenin-labeled riboprobe (Epicentre). (C) Specific, granular, bright red labeling localized to bacterial inclusions is apparent in this gill section that received the 'Candidatus Piscichlamydia salmonis' 16S rDNA riboprobe. (D) Signal development is limited to bacterial inclusions in branchial epithelial cells. Scale bars $=10 \mathrm{um}$

No 16S rRNA gene signature sequences were amplified from these 2 samples.

\section{Clone sequencing}

A total of 86 clones from water samples with multiple templates were sequenced in the forward and reverse directions, with at least 4 clones being sequenced from each PCR. To date, a number of $16 \mathrm{~S}$ rRNA genetic sequences from chlamydiae have been identified as being associated with epitheliocystis, e.g. 'Candidatus Piscichlamydia salmonis' (AY462244), Neochlamydia spp. (AY225593, AY225594), 'Candidatus Clavochlamydia salmonicola' (DQ011662 or EF577392), and those identified by Meijer et al. (2006) including CRG 18 (AY013394), CRG 20 (AY013396) and CRG 98
(AY013474). BLAST-n search analysis showed that none of the sequences that are currently associated with epitheliocystis were identified from among the 16S rRNA genetic sequences amplified from the water samples of the present study.

\section{DISCUSSION}

Eighteen Arctic charr from 1 farm in Canada had chlamydial inclusions that were indicative of epitheliocystis together with proliferative and inflammatory gill lesions. This farm had reported a history of epitheliocystis that was thought to be of chlamydial etiology. Proliferative gill lesions were histologically similar to those reported in previous studies of Arctic charr (Draghi et al. 2007); however, co-infection by other 
infectious agents cannot be discounted. Nowak \& LaPatra (2006) provide a detailed summary of the variety of co-infections that are reported in epitheliocystis, and while certain of these co-infections may have been identifiable in these 18 Arctic charr using light microscopy alone (e.g. Trichodina sp. or certain other protozoans), no specific testing was performed for many of these co-infecting agents (e.g. paramyxovirus or poxvirus). Inflammatory cell infiltrates, consisting of macrophages in Atlantic salmon (Nylund et al. 1998, Draghi et al. 2004) and macrophages and eosinophils in the sea bream Sparus aurata L. (Paperna 1977), have been reported in association with epitheliocystis. The cellular infiltrate of eosinophilic granular cells and neutrophils in these Arctic charr is different from that reported in other fish hosts. While this cellular infiltrate could be a response to an undetected co-infection, it could also be a temporal and/or species variation in the inflammatory response associated with epitheliocystis.

The Gimenez histochemical technique differentially stained chlamydial inclusions in gill sections from the 18 fish discussed above, and TEM revealed that these inclusions contained reticulate and intermediate bodies in an extracellular matrix; these descriptions are similar to those by Draghi et al. (2007) of the ultrastructural features of epitheliocystis inclusions in Arctic charr. Inclusions with this morphology are typical of chlamydia and not rickettsia (Avakyan \& Popov 1984, Dumler et al. 2001, Dumler \& Walker 2005). However, unlike previous studies involving epitheliocystis in Arctic charr wherein molecular analysis indicated infection by a Neochlamydia sp. (Draghi et al. 2007), molecular analyses of these 18 Arctic charr yielded chlamydial sequences that were identical (GQ302988) or nearly identical (GQ302987) to known sequences of 'Candidatus Piscichlamydia salmonis' (a chlamydia which had previously been associated with epitheliocystis in farmed Atlantic salmon, Salmo salar; Draghi et al. 2004). A $\sim 1.5 \mathrm{~kb}$ riboprobe transcribed from the 16S rRNA gene of 'Candidatus Piscichlamydia salmonis' labeled epitheliocystis inclusions in gills of these infected charr in subsequent in situ hybridization experiments, providing further evidence that the epitheliocystis inclusions identified in histologic sections of gills were the source of the 16S rRNA signature region sequence amplified from infected charr. This is the first evidence of 'Candidatus Piscichlamydia salmonis' in epitheliocystis inclusions of Arctic charr. 'Candidatus Piscichlamydia salmonis' is the second bacterium of the Chlamydiae that has been found to be associated with epitheliocystis in Arctic charr, the previous one being a Neochlamydia sp. (Draghi et al. 2007). Prior reports have suggested that species of chlamydia may be host-specific (Meijer et al. 2006). These results suggest otherwise and also provide evidence that 'Candidatus Piscichlamydia sal- monis' can infect at least 1 salmonid host (e.g. Arctic charr) under freshwater conditions.

The ultrastructural morphology of the chlamydial inclusions in the studied charr was similar to that previously reported in charr infected with a Neochlamydia sp., particularly with respect to the presence of an osmiophilic fibrillar extracellular matrix between reticulate bodies within the inclusion proper (Draghi et al. 2007). In contrast, such an extracellular matrix was not present in the inclusions of 'Candidatus Piscichlamydia salmonis' in Atlantic salmon, although scant loose fibrillar material was present between reticulate bodies within inclusions (Draghi et al. 2004). Reasons for these differences in inclusion morphology may be related to the growth phase and maturity of the inclusion at the time of sampling, to environmental factors such as salinity and temperature, or to yet undetermined elements of the host-bacterium interaction that may contribute to inclusion formation. For example, the Atlantic salmon which were host to 'Candidatus Piscichlamydia salmonis' resided in marine net-pens, whereas affected Arctic charr in this study were raised in freshwater. Moreover, the genetic diversity of 'Candidatus Piscichlamydia salmonis' and its relatives is unknown and could account for variations in such phenotypic features as inclusion formation and host range. Due to the differing methods of tissue preparation used in the present study and Draghi et al. (2007), one should interpret these similarities with caution since some substances (e.g. lipids) were removed by the paraffin embedding process prior to preparation for TEM.

Ten of the 12 16S PCR product sequences from charr gills with epitheliocystis had a single base substitution $(A->$ G) at position 126 that distinguished this sequence from that of other 16S rDNA signature region sequences of 'Candidatus Piscichlamydia salmonis', e.g. AY462244. Since this base substitution was a consistent finding in 10 different PCRs from 10 separate gill samples from 10 charr, it seems reasonable to assert that this could represent a sequence variant in 'Candidatus Piscichlamydia salmonis'. As the level of genetic diversity in 'Candidatus Piscichlamydia salmonis' is unknown, identification of sequence variants such as this one could provide insight into the level of sequence variation in geographically distant isolates, which could have relevance to molecular phylogenetic studies or to attempts to develop molecular probes for detection of 'Candidatus Piscichlamydia salmonis'.

A unique chlamydia-like sequence (FJ168566) was amplified from a single fish with epitheliocystis inclusions; this sequence had $>80 \%$ nucleotide identity with sequences of members of the Order Chlamydiales, but was $<92 \%$ identical to any known chlamydial sequence, suggesting that this is a novel chlamydialike sequence. This chlamydial sequence has yet to be 
associated with epitheliocystis in any fish species and may represent yet another chlamydia associated with epitheliocystis. Further molecular studies using techniques such as in situ hybridization are required to confirm this observation and to characterize the occurrence of this sequence. Nevertheless, identification of this unique sequence along with sequences GQ302987 and GQ302988 from charr at the studied location is the first evidence suggesting the presence of multiple chlamydial species associated with epitheliocystis during an outbreak of the disease.

The water-borne life stages of chlamydiae associated with epitheliocystis may not be readily detectable by broadly applied PCR assays, perhaps because these chlamydiae may not be the most prevalent environmental chlamydiae or are no longer in the water column at the time of testing. Nonetheless, to date, 'Candidatus Piscichlamydia salmonis' has been identified in samples from distant geographic locations, e.g. Ireland, Norway and now North America. The results of this study and Draghi et al. (2004) suggest that 'Candidatus Piscichlamydia salmonis' is an important pathogen of at least 2 commercially relevant species of salmonids and is capable of causing infection in freshwater and marine environments. Furthermore, it seems that the chlamydiae associated with epitheliocystis may not be host-specific. These chlamydia may even appear to be morphologically different when examined by histochemical and ultrastructural means in different hosts. Moreover, there may be one or more sequence variants among the chlamydia associated with epitheliocystis within a population during a given infection, further emphasizing the importance of molecular characterizations of the chlamydia associated with epitheliocystis. The identification of a unique sequence (FJ168566) from a gill specimen with epitheliocystis inclusions represents yet another chlamydia associated with epitheliocystis. In light of successful treatment of cultured largemouth bass for epitheliocystis (Goodwin et al. 2005), efforts to develop environmental monitoring systems or diagnostic assays targeted toward specific detection of chlamydiae associated with epitheliocystis are warranted for both freshwater and marine production scenarios.

Acknowledgements. We thank the Arctic charr producers for allowing access to their farms during this study; L. Silbart and D. Rood for support of the in situ hybridization experiments; I. Jackman and D. Woodward for expert histotechnological services; and M. Sharrer for excellent on-farm technical support. The various elements of this investigation were funded by the US Department of Agriculture, Agriculture Research Service, under agreement No. 58-1930-5-510, and by grants from the University of Connecticut Research Foundation, the USDA Cooperative State Research, Education and Extension Service, the Storrs Agricultural Experiment Station, and the Connecticut Sea Grant College Program.

\section{LITERATURE CITED}

Altschul SF, Gish W, Miller W, Myers EW, Lipman DJ (1990) Basic local alignment search tool. J Mol Biol 215:403-410 Altschul SF, Madden TL, Schäffer AA, Zhang J, Zhang Z, Miller W, Lipman DJ (1997) Gapped BLAST and PSIBLAST: a new generation of protein database search programs. Nucleic Acids Res 25:3389-3402

Amann R, Springer N, Schonhuber W, Ludwig W, Schmid EN, Muller KD, Michel R (1997) Obligate intracellular bacterial parasites of acanthoamoebae related to Chlamydia spp. Appl Environ Microbiol 63:115-121

> Avakyan AA, Popov VL (1984) Rickettsiae and chlamydiae: comparative electron microscopic studies. Acta Virol 28: 159-173

> Bradley TM, Newcomer CE, Maxwell KO (1988) Epitheliocystis associated with massive mortalities of cultured lake trout Salvelinus namaycush. Dis Aquat Org 4:9-17

Brown C (1998) In situ hybridization with riboprobes: an overview for veterinary pathologists. Vet Pathol 35:159-167

Collingro A, Poppert S, Heinz F, Schmitz-Esser S and others (2005) Recovery of an environmental chlamydia strain from activated sludge by co-cultivation with Acanthamoeba sp. Microbiology 151:301-309

> Corsaro D, Greub G (2006) Pathogenic potential of novel chlamydiae and diagnostic approaches to infections due to these obligate intracellular bacteria. Clin Microbiol Rev 19:283-297

> Corsaro D, Venditti D (2004) Emerging chlamydial infections. Crit Rev Microbiol 30:75-106

Corsaro D, Venditti D, Valassina M (2002) New chlamydial lineages from freshwater samples. Microbiology 148: 343-344

Crespo S, Grau A, Padrós F (1990) Epitheliocystis disease in the cultured amberjack, Seriola dumerili Risso (Carangidae). Aquaculture 90:197-207

- Crespo S, Zarza C, Padrós F, Marín de Mateo M (1999) Epitheliocystis agents in sea bream Sparus aurata: morphological evidence for two distinct chlamydia-like developmental cycles. Dis Aquat Org 37:61-72

Culling CFA (1974) Handbook of histopathological and histochemical techniques, 3rd edn. Butterworths, Boston, MA

Draghi A II, Popov VL, Kahl MM, Stanton JB and others (2004) Characterization of 'Candidatus Piscichlamydia salmonis' (Order Chlamydiales), a chlamydia-like bacterium associated with epitheliocystis in farmed Atlantic salmon (Salmo salar). J Clin Microbiol 42:5286-5297

> Draghi A II, Bebak J, Popov VL, Noble AC and others (2007) Characterization of a Neochlamydia-like bacterium associated with epitheliocystis in cultured Arctic charr Salvelinus alpinus. Dis Aquat Org 76:27-38

Dumler JS, Walker DH (2005) Order II. Rickettsiales Giezczykiewicz, 1939, 25AL emend. In: Brenner DJ, Krieg NR, Staley JT (eds) Bergey's manual of systematic bacteriology, 2nd edn, Vol 2. The Proteobacteria, Part C. The alpha-, beta-, delta-, and epsilonproteobacteria. Springer, New York, p 96-145

Dumler JS, Barbet AF, Bekker CPJ, Dasch GA and others (2001) Reorganization of genera in the Families Rickettsiaceae and Anaplasmataceae in the Order Rickettsiales: unification of some species of Ehrlichia with Anaplasma, Cowdria with Ehrlichia and Ehrlichia with Neorickettsia, descriptions of six new species combinations and designation of Ehrlichia equi and 'HGE agent' as subjective synonyms of Ehrlichia phagocytophila. Int J Syst Evol Microbiol 51:2145-2165

Engel JN, Ganem D (1987) Chlamydial rRNA operons: gene 
organization and identification of putative tandem promoters. J Bacteriol 169:5678-5685

Everett KDE, Andersen AA (1997) The ribosomal intergenic spacer and domain I of the 23S rRNA gene are phylogenetic markers of Chlamydia spp. Int J Syst Bacteriol 47: 461-473

- Everett KDE, Bush RM, Andersen AA (1999) Emended description of the Order Chlamydiales, proposal of Parachlamydiaceae fam. nov. and Simkaniaceae fam. nov., each containing one monotypic genus, revised taxonomy of the Family Chlamydiaceae, including a new genus and five new species, and standards for the identification of organisms. Int J Syst Bacteriol 49:415-440

> Ewing B, Hillier L, Wendl M, Green P (1998) Base-calling of automated sequencer traces using phred. I. Accuracy assessment. Genome Res 8:175-185

Frances J, Tennent R, Nowak BF (1997) Epitheliocystis in silver perch, Bidyanus bidyanus (Mitchell). J Fish Dis 20: 453-457

Fritsche TR, Horn M, Wagner M, Herwig RP, Schleifer KH, Gautom RK (2000) Phylogenetic diversity among geographically dispersed Chlamydiales endosymbionts recovered from clinical and environmental isolates of Acanthamoeba spp. Appl Environ Microbiol 66:2613-2619

> Fukatsu T, Nikoh N (1998) Two intracellular symbiotic bacteria from mulberry psyllid Anomoneura mori (Insecta, Homoptera). Appl Environ Microbiol 64:3599-3606

Gan FY, Luk GD, Gesell MS (1994) Nonradioactive in situ hydridization techniques for routinely prepared pathology specimens and cultured cells. J Histotechnol 17:313-319

Giberson RT, Demaree RS Jr, Nordhausen RW (1997) Fourhour processing of clinical/diagnostic specimens for electron microscopy using microwave technique. J Vet Diagn Invest 9:61-67

Giberson RT, Austin RI, Charlesworth J, Adamson G, Herrera GA (2003) Microwave and digital imaging technology reduce turnaround time for diagnostic electron microscopy. Ultrastruct Pathol 27:187-196

> Gimenez DF (1964) Staining rickettsiae in yolk-sac cultures. Stain Technol 39:135-140

> Goodwin AE, Park E, Nowak BF (2005) Successful treatment of largemouth bass Micropterus salmoides (L.) with epitheliocystis hyperinfection. J Fish Dis 28:623-625

Gordon D, Abajian C, Green P (1998) Consed: a graphical tool for sequence finishing. Genome Res 8:195-202

> Groff JM, LaPatra SE, Munn RJ, Andersen ML, Osburn BI (1996) Epitheliocystis infection in cultured white sturgeon (Acipenser transmontanus): antigenic and ultrastructural similarities of the causative agent to the chlamydiae. J Vet Diagn Invest 8:172-180

Hillis DM, Dixon MT (1991) Ribosomal DNA: molecular evolution and phylogenetic inference. Q Rev Biol 66:411-453

> Hoffman GL, Dunbar CE, Wolf K, Zwillenberg LO (1969) Epitheliocystis, a new infectious disease of the bluegill (Lepomis macrochirus). Antonie van Leeuwenhoek 35: $146-158$

> Horn M, Wagner M (2001) Evidence for the additional genuslevel diversity of Chlamydiales in the environment. FEMS Microbiol Lett 204:71-74

- Horn M, Wagner M, Muller KD, Schmid EN, Fritsche TR, Schleifer KH, Michel R (2000) Neochlamydia hartmannellae gen. nov., sp. nov. (Parachlamydiaceae), an endoparasite of the amoeba Hartmannella vermiformis. Microbiology 146:1231-1239

Karlsen M, Nylund A, Watanabe K, Helvik JV, Nylund S, Plarre H (2008) Characterization of 'Candidatus Clavochlamydia salmonicola': an intracellular bacterium infec-

Editorial responsibility: Catherine Collins,

Aberdeen, UK ting salmonid fish. Environ Microbiol 10:208-218

Kim DJ, Park JH, Seok SH, Cho SA, Baek MW, Lee HY, Park JH (2005) Epitheliocystis in carp (Cyprinus carpio) in South Korea. J Vet Med Sci 67:119-120

- Kvellestad A, Falk K, Nygaard SMR, Flesja K, Holm JA (2005) Atlantic salmon paramyxovirus (ASPV) infection contributes to proliferative gill inflammation (PGI) in seawaterreared Salmo salar. Dis Aquat Org 67:47-54

> Langdon JS, Elliott K, Mackay B (1991) Epitheliocystis in the leafy sea-dragon. Aust Vet J 68:244

> Lewis EJ, McLaughlin SM, Bodammer JE, Sawyer TK (1992) Epitheliocystis in ten new host species of marine fish. J Fish Dis 15:267-271

> McDowell EM, Trump BF (1976) Histologic fixatives suitable for diagnostic light and electron microscopy. Arch Pathol Lab Med 100:405-406

Meijer A, Roholl PJM, Ossewaarde JM, Jones B, Nowak BF (2006) Molecular evidence for association of chlamydiales bacteria with epitheliocystis in leafy seadragon (Phycodurus eques), silver perch (Bidyanus bidyanus), and barramundi (Lates calcarifer). Appl Environ Microbiol 72:284-290

> Nowak BF, Clark A (1999) Prevalence of epitheliocystis in Atlantic salmon, Salmo solar L., farmed in Tasmania, Australia. J Fish Dis 22:73-78

> Nowak BF, LaPatra SE (2006) Epitheliocystis in fish. J Fish Dis 29:573-588

> Nylund A, Kvenseth AM, Isdal E (1998) A morphological study of the epitheliocystis agent in farmed Atlantic salmon. J Aquat Anim Health 10:43-55

> Nylund A, Watanabe K, Nylund S, Karlsen M, Saether PA, Arnesen CE, Karlsbakk E (2008) Morphogenesis of salmonid gill poxvirus associated with proliferative gill disease in farmed Atlantic salmon (Salmo salar) in Norway. Arch Virol 153:1299-1309

Palys T, Nakamura LK, Cohan FM (1997) Discovery and classification of ecological diversity in the bacterial world: the role of DNA sequence data. Int J Syst Bacteriol 47: 1145-1156

> Paperna I (1977) Epitheliocystis infection in wild and cultured sea bream (Sparus aurata, Sparidae) and grey mullets (Liza ramada, Mugilidae). Aquaculture 10:169-176

Paperna I, Alves de Matos AP (1984) The developmental cycle of epitheliocystis in carp, Cyprinus carpio L. J Fish Dis 7:137-147

> Pettersson B, Andersson A, Leitner T, Olsvik O, Uhlen M, Storey C, Black CM (1997) Evolutionary relationships among members of the genus Chlamydia based on 16S ribosomal DNA analysis. J Bacteriol 179:4195-4205

Rourke AW, Davis RW, Bradley TM (1984) A light and electron microscopic study of epitheliocystis in juvenile steelhead trout, Salmo gairdneri Richardson. J Fish Dis 7: 301-309

Sheehan DZ, Hrapchak BB (1980) Theory and practice of histotechnology. Battelle Press, Columbus, $\mathrm{OH}$

> Szakolczai J, Vetesi F, Pitz SR (1999) Epitheliocystis disease in cultured pacu (Piaractus mesopotamicus) in Brazil. Acta Vet Hung 47:311-318

Wolke RE, Wyand DS, Khairallah LH (1970) A light and electron microscopy study of epitheliocystis disease in the gills of Connecticut striped bass (Morone saxatilis) and white perch (Morone americanus). J Comp Pathol 80:559-563

Zachary A, Paperna I (1977) Epitheliocystis disease in the striped bass (Morone saxatilis) from the Chesapeake Bay. Can J Microbiol 23:1404-1414

Zimmer MA, Ewing MS, Kocan KM (1984) Epitheliocystis disease in the channel catfish, Ictalurus punctatus (Rafinesque). J Fish Dis 7:407-410

Submitted: March 3, 2008; Accepted: October 26, 2009

Proofs received from author(s): February 8, 2010 